\title{
An improved method for derivatization of fatty acids for liquid chromatography
}

\author{
M. Czauderna, J. Kowalczyk and G. Chojecki \\ The Kielanowski Institute of Animal Physiology and Nutrition, \\ Polish Academy of Sciences \\ O5-llo Jablonna Poland
}

\section{ABSTRACT}

Derivatization of fatty acids is usually carried out with 2,4'-dibromoacctophenone in the presence of excess of basic species at $50^{\circ} \mathrm{C}$ for $2 \mathrm{~h}$. Under such conditions, some unsaturated fatty acids can be oxidized or isomerized. To prevent oxidation or isomerization, polyunsaturated fatty acids, particularly conjugated dienes, should be derivatized at $\sim-26^{\circ} \mathrm{C}$ for $6.5 \mathrm{~h}$. The proposed new procedure assures a decrease of degradation or isomerization of unsaturated fatty acids. This procedure provides a simple method for preparation and derivatization of fatty acids in milk, meat, fat and intestinal digesta followed by HPLC analysis with UV detection.

KEY WORDS: derivatization, fatty acids, UV detection, liquid chromatography

\section{INTRODUCTION}

It is well documented that unsaturated fatty acids (FA), particularly conjugated dienes, play an important role in the human diet in minimizing the risk of cancer, atherosclerosis, obesity, diabetes, and cardiovascular diseases (e.g., Grundy, 1999). The main sources of conjugated unsaturated fatty acids (CLA) for humans are dairy and beef products of ruminant origin. Studies on fatty acid metabolism in these organisms aimed at producing products with high proportions of desirable acids and controlling the food FA profile require reliable and sensitive methods of FA determination. In gas chromatography methods, quantification of fatty acids is based mainly on a single derivative, i.e. fatty acid methyl ester (Gutnikov, 1995; Kramer et al., 1997); in contrast, in high-performance liquid-chromatography (HPLC) methods, a great number of derivatizing agents can be used. Most FA 
assays by HPLC are performed on reverse phase columns that consist of alkyl chains of various lengths bonded to a silica base. Both retention and selectivity increase as the alkyl chain of the bonded phase is lengthened (Gutnikov, 1995). Moreover, in many cases retention and resolution efficiencies can achieve an optimum when derivatized FAs are injected onto the column. The ability to modify these parameters by using various derivatizing agents and by adding various organic solvents and buffers to the mobile phase gives HPLC more flexibility than GC in this respect. In order to improve a method's specificity or selectivity, different derivatives are applied. Underivatized FAs or their methyl esters have a high molar absorption at low UV wavelengths $(\lambda<205 \mathrm{~nm})$ in which many suitable mobile phase components are not transparent (Czauderna and Kowalczyk, 2001). Therefore, for analytical applications it is better to use derivatizing reagents possessing high molar absorption at longer UV wavelengths $(\lambda<230 \mathrm{~nm})$. Of the many derivatives proposed for FA analysis by HPLC, substituted aromatic compounds (Gutnikov, 1995; Momchilova et al., 1998) are used more frequently. Thus, fatty acids are often derivatized with dibromoacetophenone in the presence of triethylamine (Heinig et al., 1998; Czauderna and Kowalczyk, 2001). The high molar absorption and the close proximity of the absorbance maximum to $256 \mathrm{~nm}$ make these derivatives ideally suited for analysis with UV detectors. Furthermore, derivatized FAs are substantially retained on reversed-phase columns and are clearly distinct from various endogenous substances in milk and intestinal digesta samples. The unidentified species present in biological samples did not interfere with FA derivatives detected at 252-260 nm. By manipulation of the percentage of water in acetonitrile, gradient elution systems can simultaneously fractionate mixtures of saturated fatty acids (SFAs) and some geometrical and positional isomers of unsaturated conjugated and non-conjugated FAs (Czauderna and Kowalczyk, 2001). Moreover, these HPLC methods are based on widely available $\mathrm{C}_{18}$ columns, and very simple and rapid preparation of free FA extracts.

Considering the above, the aim of this study was to provide an efficient method for the derivatization of FAs with dibromoacetophenone in the presence of triethylamine.

\section{MATERIAL AND METHODS}

\section{Reagents}

All chemicals were of analytical grade; HPLC-grade acetonitrile and methanol were purchased from POCh (Gliwice, Poland). 2,4'-dibromoacetophenone and triethylamine were from Merck (Darmstadt, Germany). Caprylic, capric, lauric, my- 
ristic, palmitic, stearic acids and nonanoic acid (an internal standard) were from Fluka, while all cis and trans unsaturated fatty acids were supplied by Sigma (USA). All other reagents were obtained from POCh (Gliwice, Poland). Water used for the preparation of mobile phases and solutions of chemical reagents was prepared using an Elix ${ }^{\mathrm{TM}}$ water purification system (Millipore, Toronto, Canada). The mobile phases were filtered through a $0.45 \mu \mathrm{m}$ membrane filter (Millipore) and then degassed for 3-4 $\mathrm{min}$ in vacuum with ultrasonication prior to use.

\section{Chromatographic equipment}

HPLC analyses were performed on a Waters 625 LC system consisting of a controller for gradient elution, two Waters pumps (Model 515 and 501). The apparatus comprised a Waters 996 photodiode array detector, a Waters ${ }^{\mathrm{TM}} 717 \mathrm{plus}$ WISP autosampler and computer data handling system (all equipment from Waters, Millipore, MA, USA). Development of the gradient elution system, collection and data integration were performed with Millennium 2001 software (version 2.15) and a Pentium III computer. All HPLC separations were performed on two Nova Pak $\mathrm{C}_{18}$ columns ( $4 \mu \mathrm{m}, 250 \times 4.6 \mathrm{~mm}$, I.D., Waters) in conjunction with a Waters guard column of $10 \times 6 \mathrm{~mm}$ l.D. containing reversed-phase $\mathrm{C}_{18}(30-40 \mu \mathrm{m})$ packing material.

\section{Preparation and hydrolysis of samples}

Milk, meat and duodenal digesta samples collected from sheep were frozen, lyophilized and the obtained residues were stored in sealed tubes under nitrogen at $-20^{\circ} \mathrm{C}$ until analyzed. Lyophilized milk $(\sim 50 \mathrm{mg})$ and duodenal digesta $(\sim 110 \mathrm{mg})$ samples were hydrolyzed with $3-4 \mathrm{ml}$ of $2 \mathrm{M} \mathrm{NaOH}$ at $85-90^{\circ} \mathrm{C}$ for $35 \mathrm{~min}$ in sealed tubes. All mixtures were protected from the light. After cooling the hydrolyzates were acidified with $4 \mathrm{M} \mathrm{HCl}$ to $\mathrm{pH} \sim 2$ and then free fatty acids were extracted four times with $3.5 \mathrm{ml}$ of dichloromethane. The lower organic layer was dried with $\mathrm{Na}_{2} \mathrm{SO}_{4}$ and then the organic solvent was removed under a gentle stream of argon (Czauderna and Kowalczyk, 2001). The residue was used for derivatization according to Heinig et al. (1998) or modified as described below.

\section{Mobile phases and gradient composition}

Two HPLC grade solvents were used in this study. The first mobile phase was acetonitrile, while the second mobile phase was water. For HPLC analysis of derivatized FAs, elutions were carried out in the gradient method developed in our previous study (Czauderna et at., 2001) using UV detection at $256 \mathrm{~nm}$ and $235 \mathrm{~nm}$ (both wavelengths only for CLA assay). 


\section{Modification of derivatization procedure}

To a residue in a reacti-vial, $0.5 \mathrm{ml}$ of dibromacetophenone $(12 \mathrm{~g} / \mathrm{L}$ in acetone) and $1.5 \mathrm{ml}$ of triethylamine $(10 \mathrm{~g} / \mathrm{L}$ in acetone) are added. The mixture should be protected from the light. The contents are mixed and reacted for $2 \mathrm{~h}$ at $50^{\circ} \mathrm{C}$ as recommended by Heinig et al. (1998) or at a modified temperature of $24^{\circ} \mathrm{C}$ or $-26^{\circ} \mathrm{C}$. The derivatization reaction is stopped by adding $50 \mu \mathrm{l}$ of acetic acid $(2 \mathrm{~g} / \mathrm{L}$ in acetone). The derivatizing procedure for standards is the same as for biological samples. The resulting solutions are injected onto chromatographic columns.

\section{RESULTS AND DISCUSSION}

The composition of mixtures of geometric and positional isomers of unsaturated FAs (with emphasis on conjugated dienes) can be greatly affected by the reaction conditions used in the derivatization procedures (Shantha et al., 1993; Kramer et al., 1997; Ostrowska et al., 2000). Moreover, it is reasonable to suggest that some amounts of unsaturated FAs can be isomerized or degraded during derivatization reactions carried out for a long time and at higher temperatures. Therefore, in order to avoid the degradation or isomerization these FAs, we recommended that the original derivatization procedure (Heinig et al., 1998) be modified. Considering the above, the derivatization reaction was carried out at a lower temperature than the original derivatization procedure (i.e., $50^{\circ} \mathrm{C}$ ). Earlier results reveal (Czauderna and Kowalczyk, 2001) that milk and duodenal digesta contain short, medium, and long carbon chains of saturated fatty acids, mono- and polyunsaturated FAs, and CLA. All of these FAs can be satisfactorily quantified using binary gradient elution systems (Czauderna et al., 2001). Thus, to examine in detail the influence of duration of the derivatization reaction and temperature on the yield of FA derivatives, milk and duodenal digesta samples and the previously published HPLC method (Czauderna and Kowalczyk, 2001) were applied. Summaries of the results obtained from monitoring the composition of various FA types in milk and duodenal digesta by the modified and original derivatization method (i.e., at $-26,24$ and $50^{\circ} \mathrm{C}$ ) are given in Table 1 (for FA composition in milk or duodenal digesta see ref. Czauderna and Kowalczyk, 2001). The systematic study showed that the yield of the derivatization reaction carried out at $24^{\circ} \mathrm{C}$ was satisfactory (more than $98 \%$ ) when the concentrations of assayed FAs were examined after $2 \mathrm{~h}$ reaction. Obviously, the product formation yield increased with increasing duration of the reaction. Considering the above results, it seems reasonable to suggest that the maximum yicld of the derivatization process carried out at $50^{\circ} \mathrm{C}$ can be obtained before $2 \mathrm{~h}$ of the reaction duration. As expected, the yield of derivatives increased with duration of the reaction (Table 1), however, no observable rise of FA derivatives 
TABLE 1

Dependence of the relative yield' of derivatization reaction upon temperatures and duration of the reaction

\begin{tabular}{|c|c|c|c|c|c|}
\hline \multicolumn{2}{|r|}{$-26^{\circ} \mathrm{C}^{2}$} & \multicolumn{2}{|r|}{$24^{\circ} \mathrm{C}$} & \multicolumn{2}{|r|}{$50^{\circ} \mathrm{C}$} \\
\hline Time & Relative yield, $\%$ & Time & Relative yield, $\%$ & Time & Relative yield, $\%$ \\
\hline $25 \min$ & 14.4 & $15 \mathrm{~min}$ & 35.3 & $15 \mathrm{~min}$ & 42.9 \\
\hline $2 \mathrm{~h}$ & 18.5 & $2 \mathrm{~h}$ & 98.1 & $45 \mathrm{~min}$ & 86.8 \\
\hline $4 \mathrm{~h}$ & 26.0 & $4 \mathrm{~h}$ & 121.0 & $1 \mathrm{~h}$ & 98.7 \\
\hline $6.5 \mathrm{~h}$ & 43.0 & - & - & $1.5 \mathrm{~h}$ & 100.2 \\
\hline $23 \mathrm{~h}$ & 45.9 & - & - & - & - \\
\hline
\end{tabular}

1 the relative yield ( $Y_{r}$ ) was calculated as: $Y_{r}=\left(C_{F A s}{ }^{x} / C_{F A s}{ }^{\text {unig }}\right) \times 100 \%$, where $C_{F_{A s}}{ }^{x}$ is concentration of FAs derivatives at examined temperature and $\mathrm{C}_{\mathrm{FAs}}$ oris is concentration of $\mathrm{FAs}$ derivatives at $50^{\circ} \mathrm{C}$ for $2 \mathrm{~h}$ reaction (i.e. using original derivatization procedure according to Heinig et al., 1998)

2 formed precipitate should be dissolved using quickly and gentle heating (up to $\sim 20^{\circ} \mathrm{C}$ )

abundance was detected after $1 \mathrm{~h}$ of the reaction. Therefore, these results proved that the original reaction (i.e., at $50^{\circ} \mathrm{C}$ ) should be carried out for $60-70 \mathrm{~min}$.

In recent years, several authors (Kramer et al., 1997; Ostrowska et al., 2000) suggested that some polyunsaturated fatty acids, especially CLA, may undergo oxidation or isomerization during derivatization procedures carried out for a long time at high temperature. So, the current importance of unsaturated FAs and CLA (Kramer et al., 1997; Griinari et al., 2000; Mir et al., 2000; Ostrowska et al., 2000), as well as features of the chemistry involved, stimulated our research to investigate the derivatization reaction at a very low temperature. Therefore, the number of products of the reaction was determined at $-26^{\circ} \mathrm{C}$ (Table 1). As expected, the influence of temperature on derivative yield was observed. A systematic study of the effect of the duration of the reaction on the product yield has shown that the yield at $-26^{\circ} \mathrm{C}$ is lower than at $24^{\circ} \mathrm{C}$. However, even after $2 \mathrm{~h}$ reaction at $-26^{\circ} \mathrm{C}$ the concentration of derivatized FAs can be easily detected using a Waters 996 photodiode array detector. Obviously, the abundance of converted FAs increased with duration of the derivatization reaction. Contrary to expectations, for this reaction carried out at $-26^{\circ} \mathrm{C}$ no substantial increase of product concentration was observed after $6.5 \mathrm{~h}$ reaction.

Examining the derivatization reaction, we found that a much better yield was achieved in a solution containing a large excess of basic species. As extractions were carried out from acidified hydrolyzates (see section Preparation and hydrolysis of samples), we showed that a maximum yield of FA derivatives was always obtained when a greater amount of triethylamine was utilized in the derivatization procedure (i.e., $0.5 \mathrm{ml}$ of $2,4^{\prime}$-dibromoacetophenone and $1.5 \mathrm{ml}$ of triethylamine solutions). 


\section{CONCLUSIONS}

The proposed new procedure decreases the risk of degradation of unsaturated FAs without reducing the limits of detection and quantification of FAs. For very easily oxidized and isomerized unsaturated FAs (especially conjugated dienes) we suggest that the derivatization procedure be carried out at very low temperatures (at $-26^{\circ} \mathrm{C}$ ) for $6.5 \mathrm{~h}$. Obviously, FA derivatization at very low temperatures excludes the risk of degradation of unsaturated FAs, however, it slightly reduces the sensitivity of FA assays.

The proposed procedure provides a simple method for the preparation and derivatization of FAs in milk, meat, fat, and intestinal digesta samples followed by HPLC analysis. No essential changes in the levels of FA derivatives in standards, milk, meat, fat or intestinal digesta were found when processed samples were protected from the light and stored for 35 days at $-26^{\circ} \mathrm{C}$.

\section{REFERENCES}

Czauderna M., Kowalczyk J., 2001. Separation of some mono-, di- and tri-unsaturated fatty acids containing eighteen carbon atoms by high-performance liquid chromatography and photodiode array detection. J. Chromatogr. B (in press)

Czauderna M., Kowalczyk J., Potkański A., Szumacher-Strabel M., Chojecki G., 2001. Quantification of conjugated linoleic acid and other essential fatty acids in ovine meat, milk, fat and intestinal digesta. J. Anim. Feed Sci. 10, Suppl. 2, 385-392

Griinari J.M., Corl B.A., Lacy S.H., Chouinard P.Y., Nurmela K.V.V., Bauman D.E., 2000. Conjugated linoleic acid is synthesized endogenously in lactating dairy cows by $\Delta^{9}$-desaturase. J. Nutr. 130, 2285-2291

Gutnikov G., 1995. Fatty acid profiles of lipid samples. J. Chromatogr. 67, 71-89

Heinig K., Hissner F., Martin S., Vogt C., 1998. Separation of saturated and unsaturated fatty acids by capillary electrophoresis and HPLC. Amer. Lab., May, 24-29

Kramer J.K.G., Fellner V., Dugan M.E.R., Sauer F.D., Mossoba M.M., Yurawecz M.P., 1997. Evaluating acid and base catalysts in the methylation of milk and rumen fatty acids with special emphasis on conjugated dienes and total trans fatty acids. Lipids 32, 1219-1228

Mir Z., Rushfeldt M.L., Mir P.S., Paterson L.J., Weselake R.J., 2000. Effect of dictary supplementation with either conjugated linoleic acid (CLA) or linoleic acid oil on the CLA content of lamb tissues. Small Ruminant Res. 36, 25-31

Momchilova Sv., Nikolova-Damyanova B., Christie W.W., 1998. Silver ion high-performance liquid chromatography of isomeric cis- and trans-octadecenoic acids. J. Chromatogr. A 793, 275-282

Ostrowska E., Dunshea F.R., Muralitharan M., Cross R.F., 2000. Comparison of silver-ion highperformance liquid chromatographic quantification of free and methylated conjugated linoleic acids. Lipids 35, 1147-1153

Shantha N.C., Decker E.A., Hennig B., 1993. Comparison of methylation methods for the quantitation of conjugated linoleic acid isomers. J. AOAC Int. 76, 644-649 


\section{STRESZCZENIE}

\section{Zmodyfikowana metoda derywatyzacji kwasów tluszczowych stosowana w chromatografii cie-} czowej

W pracy opisano ulepszoną metodę derywatyzacji kwasów tłuszczowych, którą można stosować w wysokosprawnej chromatografii cieczowej. Reakcję derywatyzacji należy prowadzić w obecności znacznego nadmiaru zasady w $24^{\circ} \mathrm{C}$ przez 2 godz. Nienasycone kwasy tłuszczowe, szczególnie podatne na utlenianie i izomeryzację (np. sprzężone dieny), powinny być derywatyzowane w $-26^{\circ} \mathrm{C}$ przez 6.5 godz. Prezentowana metoda pozwala na szybkie przygotowanie i przedHPLC-kolumnową derywatyzację KT zawartych w mleku, mięsie, tłuszczu i treści przewodu pokarmowego. 